\title{
The influence of Covid-19 on the field of social security - The example of the Republic of Serbia
}

\begin{abstract}
This wide-ranging article takes a theoretical look at the implications of the SARSCoV-2 (Covid-19) virus for the concept of the securitisation of a state, encompassing the debate about whether social security occupies a place within securitisation studies. The authors point to, and explore, the concurrent presence of three social phenomena with global effects: digitalisation and business automation; securitisation of the systems of health and social protection; and the emergence of the Covid-19 pandemic with all its disruptive potential. They also consider closely how these phenomena relate to the already-troubled social position in the Republic of Serbia, alluding also to the deliberate use of the concept of securitisation to convince the population of the need to take drastic safeguarding steps, including the announcement of a state of emergency. The authors conclude broadly on the implications that Covid-19 has for socio-economic development, that social security does play a role within securitisation and, with a sharp prod to nationalisms as a response to the virus, that global problems and risks require global solutions.
\end{abstract}

Keywords: Covid-19, digitalisation, automation, securitisation, social structures, social benefits, social dialogue

Introduction

The pandemic caused by the Covid-19 virus arose as a public health crisis in China before unprecedentedly quickly, due to the mobility of people and migratory flows, encouraged by the development of traffic infrastructure, growing into a global crisis. It has changed the ways and models of business; restricted the freedom of movement and work of a large number of people; burdened health and social systems, bringing them to the limits of endurance; and led to a general change in everyday habits and conduct. Numerous practical examples confirm that the crisis is richly diverse and multidimensional, and that its duration, persistence and unexpected changes in behaviour have affected all social areas and sectors, starting with the economy, finance, health, social security, culture and education, both with different depths of coverage and with the intensity of its destructive effects.

Precisely because it is complex and multidimensional, which is multiplied by wide and diverse, never fully understood, groups of factors, [a crisis period] produces a large number of distinctly differentiated and difficult to measure effects. (Komarčević et al. 2011) 
The current pandemic is indeed such a crisis, extending to the large number of processes and phenomena that it manifests and the even denser network of their interactions and mutual conditioning.

It is very frequent to generalise a claim that, in all crisis situations, scientific disputes and ambivalent attitudes deepen and sharpen, while doctrinal and conceptual differences come to the surface both in their sharpness and in relief, which is not the case in ordinary times. We live in the information/digital age and in an increasingly complex and networked world that is changing dynamically, creating a whole new context, and therefore issues that are related to the survival, existence and security of individuals, their interest groups and society as a whole are a priority, not just in politics but also on strategic security agendas.

The result is that, both in normal circumstances and in emergency/crisis situations, issues related to social security in the field of labour law and employment, social protection and social transfers, trends in the labour market etc., due to their existential character, occupy the focus of interest both for the users of social services but also for workers themselves, employers, unions and other social partners including the state.

In the current global environment, three recent social phenomena mark a temporal sequence of changes that are having global effects: digitalisation and business automation; securitisation of the systems of health and social protection; and the emergence of the Covid-19 pandemic with all its disruptive potential. Originating from different sources and contexts, these phenomena nevertheless share a common time frame in which their apparent coincidence comes to be characterised by different and often inconceivable impacts individually, alongside the pronounced interactions between them.

Regardless of the fact that digitalisation appeared earlier in relation to the other two phenomena, in current practice, their challenges act in the same way, resulting in convergent meaning and significance. Mutually, their challenges are very similar in their problem approach as well as in their discursive formations. Although they appear from different perspectives, they are thematically and factually closely intertwined and most often lead to the same or very similar outcomes, most often generating a synergistic effect. (Čelik 2020)

\section{Direction and potential of digitalisation and securitisation under convergence with} the Covid-19 pandemic

Under the strong pressure of these global phenomena, the social sciences are in a phase of growing social complexity. Given such interaction, the level of complexity involved, unlike in earlier periods, heavily multiplies the challenges and problems, and thus imposes new reflective-conceptual requirements and frameworks. Among other things, this means defining, or redefining, the areas of social work, social protection and social security and especially their scope, focus and prospects.

\section{Correlation between digitalisation and Covid-19}

Digital transformation is not a new phenomenon. In semantic terms, digitalisation is, in short, a gradual process of adapting economic entities to disruptive changes in 
the market which include extensive changes in business and management, and thus changing relationships with customers and consumers, as a means of increasing business efficiency and competitiveness.

Digitalisation, both in the field of economy and public services, introduces numerous and profound changes, in the field of business and management as well as in the production and provision of services and, as a rule, has an impact on value creation, competitiveness, organisational design, the reward system and the progress and profiling of development strategy (Čelik 2020: 160-161).

Considering the disruptive impact of digitalisation across the economy in all other social sectors, including in social protection, research findings and empirical evidence indicate that the current pandemic and the crisis it has generated could act as a catalyst for accelerating change in automation and digitalisation, as a way firstly to amortise and then to absorb the negative effects of the pandemic. According to the latest research studies, however, digital transformation under pandemic conditions indicates the need for a major reset not only of the global economy but also of society as a whole (WEF 2020).

Since the beginning of the Covid-19 crisis, internet use has increased by seventy per cent and the use of apps has doubled while streaming services have increased by a factor of twenty. All this has dramatically increased dependence on technology in everyday life. On the other hand, the crisis caused by the spread of the pandemic has accelerated the need to make louder the call on companies to resolve the upcoming social challenges while the market itself indicates that companies must adopt digital business models in their business strategies to establish competitiveness.

Before Covid-19 struck, a company's average existence was about 75 years. That average has now dropped to 15 , thanks to technological interruptions. This environment has led to a change in competition rules and management, further jeopardising the survival of a growing number of companies, while the pandemic is causing further disruption and highlighting calls for urgent change in our economies and societies. The time has come for companies to combine two work streams and use the digital business models and technologies of the Fourth Industrial Revolution to transform their businesses and establish systemic changes.

It is estimated that the world's leading companies spent $\$ 1.2$ trillion on digital transformations in 2019, thus creating the basis for doing business in the digital age. The pandemic has, however, radically changed the forms of behaviour of all business actors, emphasising the importance of trust and market responsibility.

With respect to informatics, analytics and artificial intelligence, as well as the wide range of innovative and disruptive innovations, many public services such as health and social services can use the Covid-19 crisis to rethink the organisation of their systems, giving priority to improved access to health and social care of their large numbers of users. This implies a change in the existing paradigms that have not borne the weight of the test brought about by the current crisis. 


\section{Challenges of securitisation in the field of social protection and social security}

In the professional literature, securitisation is defined as a concept, process or analytical tool that explains and considers the way in which certain issues, topics or phenomena become a security issue through the discursive practices of social agents. It is based on the materialist assumption that security threats exist outside of the discourse, as well as on their task being to detect threats before they materialise (Ejdus 2009: 11).

According to Ole Wæver (1993), securitisation has five elements: speech act; securitising actors; functional actors; special measures; and audience.

The Copenhagen School has elaborated the concept and theory of securitisation in great detail, placing special emphasis on three key concepts: the actor or agent of securitisation; the act of securitisation; and the subject or object of securitisation. Actors or agents of securitisation represent the initiators and carriers of the whole process. These are most often key policy-makers, lobbyists, interest groups, etc. - i.e. all those who significantly influence decision-making in the field of security.

Linguistically or verbally, securitising actors mark a new phenomenon as a threat to the reference object; that is, by marking something as a matter of security significance, it becomes so as a result of such a process. Therefore, rhetoric is the basis for the protection of the reference object: it is a precondition for the materialisation of power and the realisation of the security interest. The audience (public or otherwise), through this process, may either accept the position of the securitising actors or simply reject it. The audience is, therefore, the one which decides whether something is a security threat or not and, in that way, gives support to (or indeed withdraws support from) the political elite in the protection of the reference object. In other words, this gives legitimacy to the actors to take special or emergency measures to combat that threat which, as a rule, requires the introduction of a state of emergency or establishment of an emergency situation. In practice, special measures, regardless of their nature, go beyond the scope of everyday political procedures and are located in a special area outside of politics where the use of all legitimate means is allowed to combat or eliminate this threat (Lipovac 2015: 64).

The object of securitisation is the reference value that is existentially endangered by the threat and which, on that basis, has a legitimate legal right to survival and continued existence. In this context, Hansen makes a significant distinction between the concept of the politicisation of an issue and securitisation. The politicisation of an issue means that it is of special importance and implication for a society and, for these reasons, the subject must be open to public discussion. It is clear that politicisation refers to a public decision-making or policy-making process based on discussions and negotiations on a particular topic. In contrast, the securitisation of an issue implies the transition, or transfer, of that issue to a place outside the political sphere and established procedures of action and decision-making, i.e. to a state of emergency in which completely different actors (chiefly, military security structures) are responsible for resolving that issue in the given circumstances (Klinkova 2013).

In order for securitisation to be successful, it is necessary to ensure three conditions: first, the speech act must follow a strictly-defined security grammar; second, decision-makers must possess significant social capital, i.e. possess a generally-ac- 
cepted authority to speak credibly about security; and third, the threat posed by securitising actors must be generally accepted by the audience as potentially threatening, and to have significant destructive potential (Ejdus 2017: 90).

In general, a number of securitising actors such as political elites, bureaucracies, governments, lobbyists or pressure groups have the opportunity at any given moment to decide whether or not to securitise a particular issue. In recent years, the theory of securitisation has faced serious criticism that it is not applicable in all situations given the new circumstances and environment.

Wilkinson (2007), studying this matter in the far east, concludes that the Copenhagen School needs urgently to redefine its normative concepts such as state, society and security, emphasising that the act of speech is not appropriate for other states outside the western context, where there are restrictions on speech and where securitisation can take place by other means including action.

On the other hand, representatives of the school, exploring the example of Egypt during the Arab Spring, conclude that securitisation theory presumes a basic level of stability and that it cannot therefore be applied to exceptional situations in which there is no normal policy (Greenwood and Wæver 2013).

Experts agree that the rhetorical structure of an act of securitisation consists of three elements: the occurrence of an existential threat to the survival of an object, requiring special measures to protect and secure the object exposed to the threat and justifying or legitimising the violation of regular democratic decision-making procedures.

According to Agamben, repressive state powers and the establishment of a state of emergency or emergency situation in response to threats in redefined security conditions become, or have become, as in the case of the war against terrorism, a permanent category and norm. According to leading experts in this field, a pandemic is not only a health, economic, social or security risk, it is primarily a global risk belonging to the category of unknown and unpredictable risks that are more closely defined in the American, more precisely psychological, concept of 'unknown unknowns'.

Almost all the countries of the western Balkans have applied the securitisation model in the case of the Covid-19 pandemic, albeit guided by medical and health, not security, expertise. In this way, the effect has been that the crisis has not turned into a catastrophe. The manner of application has, however, caused great controversy in scientific and professional circles but also among the professional classes due to excessive militarisation and the violation of democratic principles.

\section{Security and social security in Serbia}

The extension of numerous measures in the field of social policy to a large part of the population who are beneficiaries of state support has not only a social dimension but also a security one. This not only protects basic human rights but also provides the conditions for maintaining minimum dignity among social categories of the population, primarily in the area of protection and security.

Until the outbreak of the pandemic, social protection and social security were a traditional field of political science and sociology, and specific practice related to so- 
cial work and politics. However, after the outbreak, as a consequence of a global trend and through the securitisation process, this area has gradually entered the field of security sciences. This has fundamentally changed their meaning, nature, significance and scope.

Security has been socially constructed in all periods and so different actors give it different meanings and concepts (Malik 2015). Based on these starting points, according to Bourbeau (2015), security is not, as it is assumed, strictly defined, fixed or dispositional, but a dynamic and complex process since security needs are constantly expanding and multiplying.

The international and domestic literature points to the presence of three concepts on which security is based: the type of social and political practice; the way of enjoying well-being and welfare; and the degree of permanence. In this context, contemporary security definitions and security studies have been significantly expanded in terms of content and today include the military, political, social, economic and environmental fields (Buzan 1991). Despite this significant expansion, the field of social security has remained outside the interest of security studies, especially at national level.

Representatives of the Copenhagen School, developing and paving the way for a new concept of security, openly advocate that social security should be excluded from the conceptual and analytical frameworks of national and international security (Buzan and Hansen 2009). Their starting point is that social security, despite its great importance, is not a security area. It possesses semantic similarities with security, but the way of operationalisation and meaning of the term in the field of social protection is radically different from the use of it in the field of national security. However, these views have been heavily criticised by many other authors who emphasise that the two concepts are analytically and empirically related and that the empirical evidence indicates the need to include social security in security studies (Bilandžić 2017).

Citing numerous studies and scientific analyses, and supported by a weight of scientific authority (Tickner, Neocleous, Pampel, Tatalović, Grizold, Cvrtila, Gotz, etc.), all of which advocate the thesis of including social security in the domain of security studies, as well as the desirability of doing so, Bilandžić explains in detail and points out systematically that social security in modern conditions, and especially in crisis conditions, should become, in terms of content and function, a part of national security. This is, primarily, due to the need to respond to the threats and risks facing modern production and economies as well as the presence of foreign capital and actors whose sources of capital are often hidden.

In his concluding remarks, Bilandžić cites a framework that generates at least three reasons for the inclusion of social security in security studies. First, social security is directly related to human security and is thus related to the security of society as a legitimate and indisputable area of security studies. Secondly, the inclusion of knowledge on social security in security studies would have a qualitative effect in the creation of policy and the operationalisation of security practices. And thirdly, social security contains many classic security dimensions as it focuses on protecting vulnerable categories and ensuring their existence through social benefits. 

that:

In the school of economic law, which has a long tradition, there is the opinion

People created the state precisely to ensure their security and existence. When that security is focused on material and social existence, then it is called social security. (Šunderić, 1978: 35)

Furthermore, in social terms, the term 'social security' usually implies twopronged measures:

Towards a minimum level of subsistence and health and the maintenance of an appropriate level of income/standards. (Moore 1999: 13)

Accordingly, today it is generally accepted to divide the social security system into:

Basic social security systems and social security systems in the case of unforeseen circumstances. (Jašarević 2009: 153)

Social security is defined as the overall system of protection that a state provides to various categories of vulnerable people and families in old age, concerning the loss of job or unemployment, or due to illness, disability/injury at work, loss of a family wage earner, etc. (ILO 2003: 13). In short, social security creates a feeling among vulnerable categories that, in the event of a lack of the basic means to subsistence, there are elaborate mechanisms that seek to improve and enhance economic and social status through the application of measures of social protection. In essence, most definitions emphasise the human need for security, which is the basic root of the idea of social security.

According to new research, the social security system in Serbia faced serious challenges even before the outbreak of the pandemic and this has been even more the case in the meantime. The biggest challenges are in maintaining the pensions system, which is mostly financed from the state budget, in the context of the growing ageing of the population which is further aggravating the situation as it is leading to a chronic lack of funds. Serious problems are also present in the field of collecting social security contributions due to non-compliance with legal norms and the reporting of lower salaries to the competent state authorities as a result of the constant presence and share of the parallel grey economy.

A significant problem with chronic implications is the lack of an incentive to invest in occupational health and safety, especially when it comes to injuries at work and occupational diseases where the state has made some, but insufficient, progress. An aggravating circumstance is the rather unregulated system of reporting injuries at work and occupational diseases; this is significantly complicating the formulation of effective policies for the prevention of injuries and diseases; as well as of insurance against them.

The effectiveness of social dialogue is limited as a result of the disproportionately lower bargaining power of the weaker social partners and their capacity to influ- 
ence decisions. Furthermore, harmonisation with EU legislation in the field of labour and social legislation is not proceeding as planned. Basic regulations in this area and certain strategic documents, such as the Law on Social Protection, are from 2011 while the Social Protection Strategy is even older, dating from 2005 and which has now been completely overwhelmed. The position is particularly disappointing since Serbia is required, in the process of European integration, to be fully transposing EU regulations and harmonising its own regulations with EU law.

Due to the presence of a large number of undeclared workers and the ongoing process of enterprise restructuring, the number of labour disputes in Serbia is continuing to increase. Mediation as an alternative model for resolving disputes is still insufficiently used in disputes which is significantly burdening the work of the courts and increasing costs as a result of reduced efficiency.

In order to improve the current situation in the field of social security and to overcome the problems and challenges arising in accordance with that, the Ministry of Labour, Employment and Social Policy has adopted the National Programme for Decent Work for Serbia for the period 2019-2021 (ILO 2019). In accordance with the recommendations of the EU and the social partners within the country, national priorities are now more precisely defined, extending to a vision for the final outcome of the programme which includes intervention models, benchmarks and indicators of progress.

\section{Social security networks in Serbia during Covid-19}

From the beginning of the crisis, and during its spread and expansion, countries reacted in different ways, taking a wide set of protective measures including in the area of social protection. Only after the publication of the World Bank's summary review of government responses in the field of social protection were the conditions met for a more harmonised approach to the implementation of social measures and protections, including interventions in the field of social security (Rutkowski 2020).

Overall, more than two hundred countries have now implemented nearly 1,600 social protection measures (see Table 1), of which over sixty per cent refers to social benefits while the rest consist of one-off cash benefits. According to the analysis of the International Labour Organization, social assistance beneficiaries in the western Balkans have received, in addition to regular benefits, additional benefits of various amounts depending on the state.

Table 1 - The ten most common announced measures in the area of social protection

\begin{tabular}{|l|c|}
\hline Programme measure & No. of countries \\
\hline Introduction of benefits for workers and their families & 241 \\
\hline Introducing benefit for the poor and vulnerable & 131 \\
\hline $\begin{array}{l}\text { Introducing subsidies to or deferring or reducing the cost of } \\
\text { necessities/utilities }\end{array}$ & 116 \\
\hline Increasing the level of benefits & 219 \\
\hline
\end{tabular}




\begin{tabular}{|l|c|}
\hline Programme measure & No. of countries \\
\hline Wage subsidies & 107 \\
\hline Extending coverage & 107 \\
\hline Increasing resources/budgetary allocation & 92 \\
\hline Increasing benefit duration & 90 \\
\hline Improving delivery mechanism/capacity & 83 \\
\hline Deferring, reducing or waiving social contributions & \\
\hline
\end{tabular}

Source: ILO (2020); Figures updated on 30 November 2020

In addition to cash benefits, governments have also set aside in-kind assistance.

Serbia, however, has not increased its coverage of programmes aimed at the poorest categories during the crisis. Based on statistical indicators that are regularly updated, the largest segment of measures in Serbia has been aimed at preventing job losses and at the survival of small and medium enterprises due to their increased vulnerability.

As part of the implementation of such policies, pensioners were paid financial assistance of $€ 35$ while, after the abolition of the state of emergency, all adult citizens were paid a one-off amount of dinars to the equivalent of $€ 100$. Like other Balkan countries, Serbia applied restrictive measures, closing workplaces while encouraging working from home or part-time work, which has reduced access to services:

Along with the expansion of the crisis and its waves, the coverage of social protection services has decreased, while the demand for services has increased dramatically, especially in the conditions of the ban on movement. (Matković 2020: 6).

During the pandemic, special attention was paid to the protection of the residents of care institutions, i.e. to ensure the functioning of such institutions for the elderly and the sick, firstly since they belong to a particularly at-risk group and later because epidemic hotspots arose in many such facilities.

According to the Ministry of Finance, during the state of emergency and the Covid-19 pandemic, there was no increase in expenditure on the category of social assistance. Expenditure on a monthly basis for the first half of 2020 was stable and amounted to around 12.6 billion dinars (c. $€ 107 \mathrm{~m}$ ) (see Chart 1). However, 'other transfers to households', within the group of items of expenditure on 'social benefits and transfers', was increased in April by over six billion dinars (Ministarstva finansija 2020). 
Chart 1 - Public expenditure on social benefits and transfers, Jan-June 2020 (billion dinars)

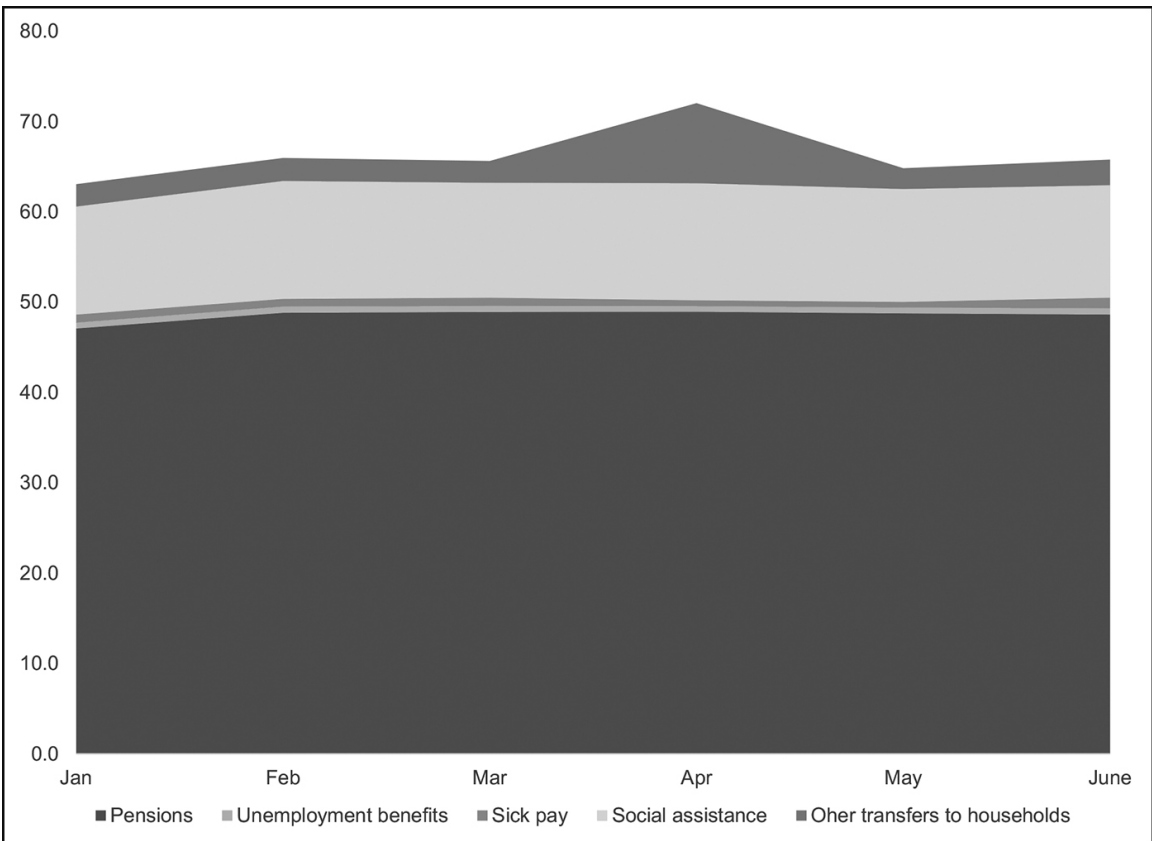

Despite the smoothness of the overall picture for the first half of 2020, in any analysis of multi-year trends since 2005 , it is evident that there has been a large increase in annual expenditures on social assistance benefits. Statistics in the category of social protection during the pandemic also record an increase in the number of beneficiaries, as well as potential new beneficiaries not previously entitled to this type of assistance (Matković 2020: 10):

Elderly households (all members older than 65)

Households in which, in addition to those over 65 , live people with disabilities

Households with one or more persons with disabilities, regardless of age

Households in distant rural/mountainous areas cut-off due to the abolition of or drastic reduction in public transport

Single parents with children with disabilities

Households in which all members are in self-isolation

Children of parents who are ill or hospitalised due to Covid-19 or other health problems

Victims of domestic violence, migrants and homeless people who did not use any services.

During the pandemic, and especially during the state of emergency, numerous regulations passed by the government of the Republic of Serbia have directly affected the employment and social status, labour rights and the everyday lives of citizens. 
Meanwhile, social protection measures have affected certain social groups in different ways, especially those who are over 65 and people who are accommodated in facilities for the elderly, people with disabilities, those with chronic diseases, people living in poor settlements without access to drinking water, etc. It is clear that the capacity of social institutions has been simply insufficient to respond to special requests made during the pandemic and the state of emergency (National Convention on the European Union 2020).

\section{Conclusions}

Covid-19 is marked as the largest pandemic in the last 100 years, and at the same time, an extremely significant threat to human existence.

Considering the scale, scope, dynamics and severity of the crisis, it is quite understandable that endangered countries are, in response to this situation, taking measures of unprecedented scope, speed and solidarity, engaging all available resources and capacities.

The pandemic has put an unparalleled series of challenges in front of the world. Up to the end of January 2021, more than $100 \mathrm{~m}$ cases of the virus had been reported, while over $2.2 \mathrm{~m}$ people had died. When it comes to the Republic of Serbia, official data show that, since the beginning of the epidemic, a total of $2.6 \mathrm{~m}$ people have been tested while the total number of patients with the virus has risen over 400,000 with more than 4,000 deaths.

A crisis of this magnitude not only has an impact on the public health sector but has far broader consequences, especially in the economic and social area where the biggest upheavals have been recorded.

According to World Bank forecasts, the Covid-19 pandemic could bring $100 \mathrm{~m}$ people into extreme poverty by 2021 and, by the end of 2020, an estimated $90 \mathrm{~m}$ people could already have reached that stage. The consequences of the pandemic on the global economy in terms of the reduction of GDP, the loss of employment and production, disturbed supply and demand in the market, the disruption of global supply and distribution chains, the increase in the rate of poverty, the limited liquidity of companies, the disruption of the European single market, etc. are multiple and have crossover effects.

Due to the new situation, numerous companies are recording a decline in profits and losses although, on the other hand, a few well-placed multinational companies are recording dramatic increases in both turnover and profit. Overall, research shows that the world economy is facing a loss of at least $\$ 126 \mathrm{bn}$ due to the pandemic (International Trade Centre 2020).

In addition to economic crisis, Covid-19 has had numerous and overwhelming consequences for the field of social protection and it will have a strongly negative impact on the situation and trends in the labour market. In addition to the loss of employment, there are significant consequences in terms of the health of workers and their families which is reflected in three ways: a reduction in the number of jobs through further automation and robotisation; a declining quality of work; and poor outcomes for those categories of employees who are especially sensitive to negative 
outcomes in the labour market, i.e. low-skilled, or 'cheap', labour which, after losing a source of income, automatically falls into the system of social protection.

Overall, and as a result of all these consequences, social protection and the social security sector is operating under strong pressure, trying to strike a balance on the one hand between the extreme level of demand for assistance or aid and, on the other, the limited financial possibilities for the realisation of this.

Some industries, such as transport, tourism, trade and catering, are recording terribly poor business results and where large shares of the workforce are in poverty. The pandemic also has political dimensions that are reflected in the centralisation of power, the militarisation of services, the drastic reduction of human rights and freedoms, the suspension of democracy, the introduction and translation of states of emergency into permanent, or long-term, situations, slowing globalisation, increasing global inequality, heightened political tensions and rising extremism, debt that is increasing globally, the collapse of economic demand and the closure of key industries. The ILO estimates that the pandemic is affecting 81 per cent of the workforce, with 2.7 billion employees out of a total of 3.3 billion workers worldwide belonging to economic entities that have stopped working due to the epidemic, either independently or following government recommendation.

In the area of security, an increase in the crime rate has been recorded, especially in the cyber field. Furthermore, the incidences of violence, civil riots and protests due to the new situation is increasing, even in those countries where this was not previously the case including in the Czech Republic, Germany, Belarus, Slovenia, etc.

Juval Noah Harari, the celebrated historian, stated in a long read for the Financial Times that, in this crisis, we face two particularly important choices: the first between totalitarian control and the empowerment of citizens' rights; the second between nationalist isolation and global solidarity (Harari 2020).

At the same time, it is evident that the pandemic has strengthened the importance of the physical availability of key production resources. The direct consequence of that, in the field of the economy, will be smaller markets that function according to a 'winner take all' philosophy, and the virtual market model will take over. Additionally Covid-19 has created a so-called isolation economy that allows all services and material goods to be remotely distributed to the consumer as well as a culture in which 'one works, learns and plays where one lives'. Significant consequences of the pandemic are also reflected in the continuation of geopolitical fragmentation and the further collapse of US domination on a global level. This will lead to a shift in geopolitical power from west to east.

On top of all the expressed reflections, interdependencies and relations, the pandemic, understood as a crisis, has brought three problems and challenges to the fore. The first is the insufficiently developed (especially in the domain of functionality) model for the global management of any issue, including pandemics; the second is the unpreparedness and poor co-ordination, with a lack of adequate early warning and rapid response plans at national level; while the third is the shortage and the limitation of resources, both human as well as material.

Covid-19, given its scope, speed and intensity of expansion, is a crucial and primary challenge to national and international security in the given circumstances. It 
constitutes, as the statistics show, a deadly risk with pronounced destructive and destabilising potential regarding the socio-economic and political order.

The key question related to the process of securitisation, but also concerning the overall response to the pandemic, comes down to the question whether the concept of 'unknown unknowns', which includes the current pandemic, can lead to the application of protective mechanisms and the ability to learn the lessons. Both analysis and practice suggest that this is not possible and that these mechanisms, experiences and prior solutions can be applied only within the framework of securitisation principles. Here, this extends to health protection and the social security sectors.

In the application of health measures and defensive-protective mechanisms, i.e. security measures, most countries, based on the process of the securitisation of these areas, have developed and applied a new response model that has a number of crucial objectives: control of the infection process and measures to localise it; preservation of health and social capacities; maintenance of minimum economic activity; statepolitical functionality; and the prevention of panic and fear among citizens. Therefore, these activities and mechanisms have been realised through co-ordinated measures in the health, social and security sector which indisputably suggests that the operation of health and social systems does indeed have a security dimension, content and connotation. In this way, in the conditions of a state of emergency, i.e. the development and inauguration of the concept of securitisation, a completely new security landscape and configuration has entered the scene.

Simply put, a securitising agent - specifically, the governments of individual countries - given fear that the pandemic might cause existential threats to the population and state institutions, turned this via discourse and various narratives into a security problem. In turn, this gave the authorities the powers to introduce an emergency situation and, in such a way, move the issue of the functioning of health and social protection and security from the regime of normal work to the regime of emergency circumstances, i.e. the situation that implies the application of emergency and special measures.

Summarising the above, it is clear that the consequences of the pandemic are multi-faceted and manifest themselves with varying strength and intensity in individual countries, areas, regions, industries, etc.

Unlike some earlier periods, when the hazards or risks were predictable and could be managed more or less successfully, modern risks are completely unpredictable while their composition and distribution exceed the capabilities of existing mechanisms to eliminate them. This implies the need to create new policies, strategies and institutional mechanisms for risk management, as well as the preparation and organisation of operational responses while strengthening logistical support mechanisms.

The securitisation models applied in health and social security will require, after the end of the pandemic, conceptual elaboration, strategic and operational profiling, as well as an adequate regulatory framework. This should include the predictability of the reactions of the state and its specialist services to all risks arising from the concept of 'unknown unknowns', which means the definition and design of new political and security agendas. This also applies to the Republic of Serbia. 
In general, the pandemic caused by the Covid-19 virus is a global risk and threat; and from that follows a strong proposition: global problems and risks can only be addressed in a global way.

\section{References}

Agamben, G (2008) Izvanredno stanje Homo sacer, II 1, Zagreb: Deltakont.

Bilandžić, M (2017) 'Socijalna politika (sigurnost) kao područje nacionalne sigurnosti: prilog raspravi o kritičkim sigurnosnim studijama' Revija za socijalnu politiku 24(3): 343-359.

Bilandžić, M and J. Pandžić (2019) 'Socijalni rad i logika sigurnosti u eri sekuritizacije terorizma’ Anali Hrvatskog politološkog društva: časopis za politologiju 16(1): 181-198.

Bourbeau, Philippe (2015) Security: Dialogue across Disciplines Cambridge: Cambridge University Press.

Buzan, Barry (1991) People, States and Fear: An Agenda for International Security Studies in the Post-Cold War Era London: Harvester Wheatsheaf.

Buzan, Barry and Lene Hansen (2009) The Evolution of International Security Studies Cambridge: Cambridge University Press.

Buzan, Barry, Ole Wæver and Jaap De Wilde (1998) Security: A New Framework for Analysis Boulder: Lynne Reiner.

Čelik, P (2020) 'Digitalna transformacija poslovanja i njene bezbednosne implikacije', Doktorska disertacija, Univerzitet privredna akademija u Novom Sadu Fakultet za ekonomiju i inženjerski menadžment u Novom Sadu.

Ejdus, F (2009) 'Opasne veze - Teorija sekuritizacije i Šmitovsko nasleđe’ Bezbednost Zapadnog Balkana, Časopis Beogradske škole za studije bezbednosti, broj 13, April-June, Beograd: Centar za civilno-vojne odnose.

Ejdus, F (2016) 'Diskurzivna i praktična konstrukcija međunarodne (ne)bezbednosti' in D. Jović Konstruktivističke teorije međunarodnih odnosa Fakultet političkih znanosti Sveučilišta u Zagrebu.

Ejdus, F (2017) Međunarodna bezbednost: teorije, sektori i nivoi Beograd: Službeni glasnik.

Greenwood, M. T and O. Wæver (2013) 'Copenhagen-Cairo on a Roundtrip: A Security Theory Meets the Revolution’ Security Dialogue 44(5-6): 485-506.

Harari, Y. N (2020) 'The world after coronavirus' Financial Times 20 March 2020, accessed 3 February 2021 at: https:/www.ft.com/content/19d90308-6858-11 ea-a 3c9-1fe6fedcca75.

ILO (2003) 'A Universal Challenge: Social Security for the World' World of Work 49: 11-13.

ILO (2019) 'Program dostojanstvenog rada za Republiku Srbiju 2019. do 2022' Geneva: ILO. 
ILO (2020) 'Social protection responses to COVID-19 crisis around the world' available online at: https://www.social-protection.org/gimi/ShowWiki.action?id=3417 [last accessed 3 February 2021].

International Trade Centre (2020) 'SME Competitiveness Outlook 2020' available at: https://www.intracen.org/smeco2020/ [last accessed 3 February 2021].

Jašarević, S (2009) 'Socijalna sigurnost i socijalna država' Zbornik radova Pravnog fakulteta u Novom Sadu, broj 3, pp. 151-165.

Klingova, K (2013) Securitization of Cyber Space in the United States of America, the Russian Federation and Estonia Budapest: Central European University.

Komarčević, M, Lj. Pejanović and M. Živojinović (2011) 'Tehnologija primene FID - Operacija u procesu razbijanja Jugoslavije’ Kultura polisa god. VIII, broj. 15, str. 27-42.

Lipovac, M and T. Simić (2015) 'Sekuritizacija u energetskoj bezbednosti - slučaj EU i ruskog gasa’ Međunarodna politika 1160: 59-77.

Malik, Shahin (2015) 'Constructing security' in Peter Hough, Shahin Malik, Andrew Roberts and Bruce Pilbeam (Eds) International Security Studies: Theory and practice Abingdon: Routledge, pp. 72-84.

Matković, G (2020) 'Mreže socijalne sigurnosti u vreme Covid-19 krize' Tim za socijalno uključivanje i smanjenje siromaštva, Beograd.

Ministarstva finansija (2020) Bilten javnih finansija last accessed 3 February 2021 at: https://www.mfin.gov.rs/vrsta-aktivnosti/bilten-javnih-finansija/.

Moore, V (1999) 'The Concept of Social Security' in: M. P. Olivier et al. (Eds.) Social Security Law (General Principles) Butterworths.

National Convention on the European Union (2020) 'Measures during state of emergency in the area of social policies and employment, public health and protection of consumers and education' Monitoring Report No. 3, available via https://eukonvent.org and specifically (in English) at https://uploads-ssl.webflow.com/5e9 038a5fc30d378d256622b/6017d2f1675273267636d437 Analysis\%20COVID\%2 33_Social\%20Policy.pdf [last accessed 3 February 2021].

Rutkowski, M (2020) 'How social protection can help countries with Covid-19' Voices, World Bank blog, 15 April, accessed 3 February 2021 at: https://blogs.wo rldbank.org/voices/how-social-protection-can-help-countries-cope-covid-19.

Šunderić, B (2001) 'Pravo Međunarodne organizacije rada’ Beograd: Pravni fakultet Univerziteta u Beogradu.

Šunderić, B (2009) Socijalno pravo Beograd: Pravni fakultet Univerziteta u Beogradu.

Teiler, Tobias (2010) 'Societal security' in Myriam D. Cavelty and Victor Mauer (Eds) Routledge Handbook of Security Studies 1st edition, Abingdon: Routledge, pp. 105-114. 
Wæver, O. (1993) 'Societal Security: The Concept' in O. Wæver, B. Busan, M. Kelstrop and P. Lemaitre (Eds) Identity, Migration and the New Security Agenda in Europe London: Pinter.

WEF (2020) Digital Transformation: Powering the Great Reset.

Wilkinson, C (2007) 'The Copenhagen School on Tour in Kyrgyzstan: Is Securitization Theory Useable Outside Europe?’ Security Dialogue 38(1): 5-25.

Miodrag Komarčević PhD is Professor of Vocational Studies at Visoka Škola za Preduzetništvo, Majke Jevrosime 15, 11000 BEOGRAD, Republic of Serbia. e-mail: miodrag.komarcevic@vssp.edu.rs.

Petar Čelik $\mathrm{PhD}$ is Lecturer in Vocational Studies at Visoka Škola za Preduzetništvo, Majke Jevrosime 15, 11000 BEOGRAD, Republic of Serbia. e-mail: petar.celik@vssp.edu.rs.

Ivan Arnautovic $\mathrm{PhD}$ is Professor and expert in economics and finance at Visoka Škola za Preduzetništvo, Majke Jevrosime 15, 11000 BEOGRAD, Republic of Serbia. e-mail: ivan.arnautovic@vssp.edu.rs.

\section{(C) $(\Theta \Theta$}

(C) Miodrag Komarčević, Petar Čelik and Ivan Arnautović 